\title{
A comprehensive study on seroprevalence of bluetongue virus in Haryana state of India
}

Sushila Maan ${ }^{1}$, Anuj Tiwari ${ }^{1,2}$, Deepika Chaudhary ${ }^{1}$, Anita Dalal ${ }^{1,3}$, Nitish Bansal ${ }^{1}$, Vinay Kumar ${ }^{1}$, Kanisht Batra ${ }^{1}$, Aman Kumar ${ }^{1}$, Naresh Kumar Kakker ${ }^{3}$ and Narender Singh Maan ${ }^{4}$

\begin{abstract}
1. Department of Animal Biotechnology, College of Veterinary Sciences, Lala Lajpat Rai University of Veterinary and Animal Sciences, Hisar - 125 004, Haryana, India; 2. Department of Veterinary Microbiology, G. B. Pant University of Agriculture and Technology, Pantnagar - 263 145, Uttarakhand, India; 3. Department of Veterinary Microbiology, College of Veterinary Sciences, Lala Lajpat Rai University of Veterinary and Animal Sciences, Hisar - 125 004, Haryana, India; 4. Department of Animal Nutrition, College of Veterinary Sciences, Lala Lajpat Rai University of Veterinary and Animal Sciences, Hisar - 125 004, Haryana, India.

Corresponding author: Sushila Maan, e-mail: sushilamaan105@gmail.com

Co-authors: AT: anuj474@gmail.com,DC: deepikachaudhary3@yahoo.com, AD: dranitadalal@gmail.com, NB: nitish0008@gmail.com,VK: 2008v60b@gmail.com, KB: drkanishtbatra@gmail.com, AK: amankumar34237@gmail.com, NK: nkmksk@rediffmail.com, NSM: narendermaan108@gmail.com

Received: 07-07-2017, Accepted: 29-10-2017, Published online: 13-12-2017
\end{abstract}

doi: 10.14202/vetworld.2017.1464-1470 How to cite this article: Maan S, Tiwari A, Chaudhary D, Dalal A, Bansal N, KumarV, Batra K, Kumar A, Kakker N, Maan NS (2017) A comprehensive study on seroprevalence of bluetongue virus in Haryana state of India, Veterinary World, 10(12): 1464-1470.

\begin{abstract}
Aim: The aim of present study was to determine seroprevalence of bluetongue virus (BTV) in Haryana state of India.

Materials and Methods: A total of 803 serum samples, 408 of cattle and 395 of buffalo origin, respectively, were collected from different villages of Haryana. Sampling was done randomly to obtain unbiased results. The samples were evaluated by a competitive enzyme-linked immunosorbent assay for the presence of BTV antibodies.

Results: Overall seroprevalence of BTV antibody in cattle and buffaloes for all 21 districts of Haryana state was found to be $75.49 \%$ and $92.91 \%$, respectively. The prevalence of BTV in different agroclimatic zones ranged between $72-77 \%$ and $90-94 \%$ for cattle and buffalo, respectively. In buffaloes, the BTV seroprevalence was comparatively higher than in cattle.
\end{abstract}

Conclusion: The study showed that BTV is circulating in cattle and buffalo populations in the Northern part of India.

Keywords: bluetongue, bluetongue virus, buffalo, cattle, competitive enzyme-linked immunosorbent assay, Haryana, India, serology.

\section{Introduction}

Bluetongue (BT) is an arthropod-borne disease of wild and domestic animals caused by bluetongue virus (BTV) of genus Orbivirus in the Reoviridae family $[1,2]$. The disease is characterized by fever, facial edema, hemorrhages, and ulceration on the oral mucosa and coronitis. Cattle and buffaloes are sub-clinically affected and are carriers of BTV. Even though this true for many strains of the virus, however, during the European outbreak of BT caused by BTV-8 in 2006, the cattle were severely affected [3]. The clinical signs in BTV-8 affected sheep flocks and cattle herds in 2007 and 2006 were similar.

BTV is not contagious, and it is transmitted by Culicoides vector midges [4,5]. In India, the disease is endemic particularly in Southern states namely, Tamil Nadu, Karnataka, Kerala, and Andhra Pradesh. To date, 27 serotypes of this virus have been reported worldwide; however, there are further putative

Copyright: Maan, et al. Open Access. This article is distributed under the terms of the Creative Commons Attribution 4.0 International License (http://creativecommons.org/licenses/by/4.0/), which permits unrestricted use, distribution, and reproduction in any medium, provided you give appropriate credit to the original author(s) and the source, provide a link to the Creative Commons license, and indicate if changes were made. The Creative Commons Public Domain Dedication waiver (http://creativecommons.org/ publicdomain/zero/1.0/) applies to the data made available in this article, unless otherwise stated. serotypes reported recently [6-10]. There is a low level of cross-protection among different serotypes, thus creating difficulties when designing of vaccines, vaccination strategies, and planning control measures [11]. Fifteen BTV serotypes have been isolated in India (BTV-1, -2, -3, -4, -5, -8, -9, -10, -12, -16, $-17,-18,-21,-23$, and -24$)$, eleven of these in the past decade, with serological evidence of presence of eight more (BTV-6, -7, -11, -13, -14, -15, -19, and -20) [12]. BT outbreaks result in an estimated 3 billion USD/ annum losses across the globe, both directly and indirectly $[13,14]$. Although there are no precise figures for economic losses due to BT in India, a study published in 2009 assessed the economic losses due to important diseases of sheep in India between 1991 and 2005, and BT was found to cause more economic devastation than foot and mouth disease (FMD), peste des petits ruminants, sheep and goat pox, anthrax, fascioliasis/distomatosis, and enterotoxemia [15]. The greatest direct losses to farmers due to BT occurred in 2005, amounting to approximately 231 million rupees [16]. Direct losses are a result of mortality and decline in production of affected animals. Indirect losses are due to trade embargoes and animal movement restrictions [1].

Due to its huge economic importance, it is paramount to detect BTV infection both in endemic and 
BTV-free countries. Complement fixation test, agar gel immunodiffusion (AGID), and competitive enzymelinked immunosorbent assay (c-ELISA) are the OIE recommended methods for BT testing for international trade [17]. Of these 3 tests, the c-ELISA has proven to be highly sensitive. It can be used to detect antibodies raised against all BTV serotypes [15]. The specificity of this test is due to the use of monoclonal anti-VP7 which can distinguish the BT serogroup from other orbivirus serogroups, for example, epizootic hemorrhagic disease virus (EHDV) [18-20]. It has been found that the diagnostic sensitivity and specificity of c-ELISA is $87.8 \%(85.10-91.10)$ and $98.2 \%$ (96.30-99.60), respectively [21]. Therefore, the antibody detecting VP7-based c-ELISA was employed in this study to determine the seroprevalence of BTV in Haryana state of India.

In India, a few studies have been conducted on seroprevalence of BT, but their results do not have much significance due to testing of less/small number of samples. This is the first substantive seroprevalence study of BT in Haryana state based on random sampling and testing of a large number of serum samples from cattle and buffaloes.

\section{Materials and Methods}

\section{Ethical approval}

Ethical approval from Institutional Animal Ethics Committee was not required as no part of research had been carried out in live laboratory or domestic animals.

\section{Animals}

The blood samples were collected from 803 animals (cattle and buffaloes) from 80 villages of 21 district of Haryana. The details of animals are given in Table-1.

\section{Study area}

Haryana is one of the northern states of India situated between $27^{\circ} 37^{\prime}$ to $30^{\circ} 35^{\prime}$ latitude and between $74^{\circ} 28^{\prime}$ to $77^{\circ} 36^{\prime}$ longitude and with an altitude between 700 and $3600 \mathrm{ft}$ above sea level. Haryana is primarily an agricultural state. The general slope of the terrain is from north-east to south-west and west with an exception in the south in Bhiwani, Mahendragarh, Rewari, and Gurgaon districts where the slope is toward north. Most of the year, the climate of Haryana is very hot in summer (May to June) and markedly cold in winter (December and January) where as in between are the pleasant months of spring. The rainfall in the region is low and erratic except in parts of Karnal, Kurukshetra, and Ambala districts ranging from $300 \mathrm{~mm}$ in the southwest to $1100 \mathrm{~mm}$ in the northeast of the state. The samples were collected throughout the year.

\section{Serum samples}

Serum was separated from $5 \mathrm{ml}$ of blood collected from cattle and buffaloes, which was stored at $-20^{\circ} \mathrm{C}$ until further use. A total of 803 serum samples,
408 from cattle and 395 from buffaloes, were collected through RRC-FMD from 80 villages of Haryana in 2014. These blood samples were taken from animals in the field, by qualified veterinarians, as part of normal veterinary care and diagnostic testing procedures in the Haryana, India. The statistical model is described as follows.

\section{Statistical model for random sampling and sample size determination}

To conduct serosurveillance studies in Haryana state, a model was designed for random sampling using SPSS software. The number of samples to be tested was calculated as described below. Villages having cattle/buffalo population more than 200 were taken for statistical analysis. The prevalence of BT was considered as $50 \%$ with $95 \%$ confidence interval. Using these values, random sampling model was designed. The above values along with the animal population data as per $19^{\text {th }}$ livestock census of 2012 for all villages in Haryana were used to obtain the number and name of villages for random sampling (http:// pashudhanharyana.gov.in/html/pdf\%20\&\%20downloads/LC\%202012/Districtwise\%20Livestock\%20 Census\%202012.pdf).

\section{C-ELISA}

The c-ELISA kits were procured from the Veterinary Medical Research and Development, USA. The ELISA was performed as per the manufacturer's instructions. Briefly, $25 \mu 1$ of neat serum, positive control, and negative control were added to antigen (VP7) pre-coated plates in duplicates and test samples in a single well. These plates were then firmly tapped 14 times on the long sides and incubated for $15 \mathrm{~min}$ at room temperature (RT). $25 \mu 1$ of antibody peroxidase conjugate was then added to each well, tapped firmly, and further incubated for $15 \mathrm{~min}$ at RT. Plates were then washed 3 times using wash solution, and remaining sera was removed by striking the inverted plates 4 times on a clean paper towel. Thereafter, $50 \mu 1$ of substrate was added, and plates were tapped firmly and incubated for $10 \mathrm{~min}$ at RT. $50 \mu \mathrm{l}$ of stop solution was added, and immediately, the plates were read in a microplate spectrophotometer at $620 \mathrm{~nm}$. The plates were deemed pass if the mean of negative control optical density (OD) was $0.300-2.00$ and mean of the positive control was $<50 \%$ of the mean of negative control. Test samples were considered positive if they produce OD $<50 \%$ of the mean of negative controls and negative if they produce OD $>50 \%$ of the mean of negative controls.

\section{Results}

Based on the random sampling mode, a total of 803 serum samples, 408 from cattle and 395 from buffaloes, were collected from 80 different villages of 21 districts of Haryana (Figure-1). In Haryana, the domestic animal population is dominated by buffaloes (6.08 million - 69\%) and cattle (1.80 million 
Table-1: Details of animals from which samples were collected.

\begin{tabular}{|c|c|c|c|c|c|c|c|}
\hline District & Animal ID & Species & Adult & Heifers & Young & Female & Male \\
\hline \multicolumn{8}{|l|}{ A: Buffalo } \\
\hline Rohtak & 20 & Buffalo & 20 & & & 16 & 4 \\
\hline Faridabad & 11 & Buffalo & 9 & 2 & & 11 & \\
\hline Jind & 20 & Buffalo & 20 & & & 13 & 7 \\
\hline Gurgaon & 20 & Buffalo & 14 & 6 & & 20 & \\
\hline Kurukshetra & 12 & Buffalo & 12 & & & 11 & 1 \\
\hline Rewari & 30 & Buffalo & 13 & 11 & 6 & 28 & 2 \\
\hline Sirsa & 20 & Buffalo & 20 & & & 20 & \\
\hline Panipat & 20 & Buffalo & 17 & 3 & & 20 & \\
\hline Kaithal & 10 & Buffalo & 8 & 2 & & 8 & 2 \\
\hline Mewat & 20 & Buffalo & 12 & 8 & & 17 & 3 \\
\hline Jhajjar & 20 & Buffalo & 14 & 6 & & 19 & 1 \\
\hline Fatehabad & 20 & Buffalo & 18 & 2 & & 20 & \\
\hline Bhiwani & 20 & Buffalo & 20 & & & 20 & \\
\hline Hisar & 12 & Buffalo & 11 & 1 & & 12 & \\
\hline Ambala & 20 & Buffalo & 20 & & & 20 & \\
\hline Sonepat & 20 & Buffalo & 20 & & & 20 & \\
\hline Palwal & 20 & Buffalo & 17 & 2 & 1 & 19 & 1 \\
\hline Panchkula & 20 & Buffalo & 18 & 2 & & 19 & 1 \\
\hline Yamunanagar & 20 & Buffalo & 13 & 5 & 2 & 17 & 3 \\
\hline Mahendragarh & 20 & Buffalo & 15 & 5 & & 20 & \\
\hline Karnal & 20 & Buffalo & 18 & 2 & & 18 & 2 \\
\hline Total & 395 & Buffalo & 329 & 57 & 9 & 368 & 27 \\
\hline \multicolumn{8}{|l|}{ B: Cattle } \\
\hline Faridabad & 10 & Cattle & 7 & 2 & 1 & 10 & \\
\hline Sirsa & 20 & Cattle & 17 & 3 & & 20 & \\
\hline Rewari & 10 & Cattle & 6 & 2 & 2 & 8 & 2 \\
\hline Panipat & 20 & Cattle & 18 & 2 & & 20 & \\
\hline Kaithal & 30 & Cattle & 26 & 2 & 2 & 30 & \\
\hline Ambala & 20 & Cattle & 19 & 1 & & 18 & 2 \\
\hline Sonepat & 20 & Cattle & 16 & 3 & 1 & 18 & 2 \\
\hline Palwal & 20 & Cattle & 17 & 2 & 1 & 18 & 2 \\
\hline Panchkula & 20 & Cattle & 17 & 3 & & 19 & 1 \\
\hline Yamunanagar & 12 & Cattle & 12 & & & 11 & 1 \\
\hline Mewat & 20 & Cattle & 14 & 6 & & 19 & 1 \\
\hline Jhajjar & 20 & Cattle & 10 & 5 & 5 & 12 & 8 \\
\hline Fatehabad & 20 & Cattle & 20 & & & 20 & \\
\hline Bhiwani & 19 & Cattle & 19 & & & 19 & \\
\hline Hisar & 16 & Cattle & 10 & 6 & & 12 & 4 \\
\hline Karnal & 20 & Cattle & 18 & 2 & & 19 & 1 \\
\hline Mahendegarh & 20 & Cattle & 9 & 10 & 1 & 20 & \\
\hline Rohtak & 20 & Cattle & 20 & & & 12 & 8 \\
\hline Faridabad & 19 & Cattle & 17 & 2 & & 19 & \\
\hline Jind & 20 & Cattle & 19 & 1 & & 19 & 1 \\
\hline Gurgaon & 20 & Cattle & 16 & 4 & & 19 & 1 \\
\hline Kurukshetra & 12 & Cattle & 10 & 2 & & 12 & \\
\hline Total & 408 & Cattle & 337 & 58 & 13 & 374 & 34 \\
\hline
\end{tabular}

Young 0-1 year, Heifers 1-3 Year, Adult $>3$ Year

- 20.50\%), whereas sheep (0.36 million - 4.11\%), goats $(0.36$ million $-4.19 \%)$, pigs only $1.44 \%$, and remaining $0.76 \%$ constituted by other species as shown in pie chart (Figure-2).

Different districts of Haryana are divided into two agroclimatic zones, i.e. eastern and western zones as shown in Haryana map Figure-1 and Table-2. The prevalence of BTV in different agroclimatic zones ranged between $72-77 \%$ (Table-3) and $90-94 \%$ (Table-4) for cattle and buffalo, respectively. The prevalence of BTV antibodies in cattle and buffalo per district is shown in Table-5.

Overall seroprevalence of BTV antibody in cattle and buffaloes for all 21 districts of Haryana state was found to be $75.49 \%$ and $92.91 \%$, respectively.
District-wise seroprevalence in cattle was observed as follows: Gurgaon (100\%), Mahendragarh (100\%), Palwal (100\%), Rohtak (100\%), Sonepat (95\%), Bhiwani (90\%), Karnal (89.47\%), Jind (85\%), Mewat (85\%), Faridabad (80\%), Panipat, Rewari, Kurukshetra, and Fatehabad (65-70\%), Hisar and Yamunanagar (53-58\%), Sirsa (45\%), Ambala (35\%), and Kaithal (23\%), respectively.

In buffaloes of Haryana, the BTV seroprevalence was comparatively higher than in cattle, with the districts of Gurgaon, Karnal, Mahendragarh, Mewat, Palwal, Panchkula, Panipat, Rohtak, and Yamunanagar showing 100\% seropositivity. Ambala, Bhiwani, Jhajjar, Jind, and Sonepat had seroprevalences of $95 \%$. Rewari was $93 \%$ seropositive, while 


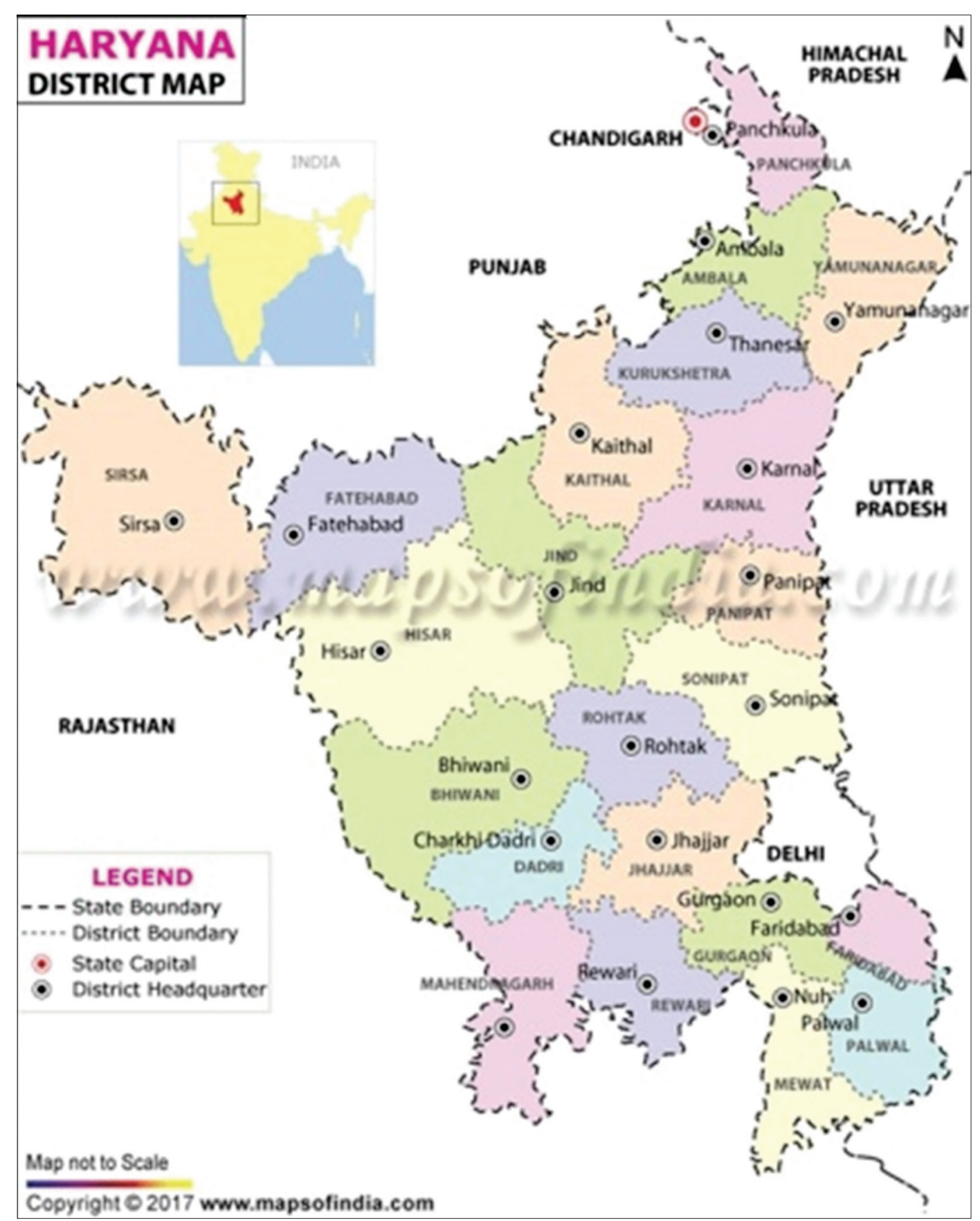

Figure-1: Study area - Haryana state districts depicted on India map.

Faridabad, Fatehabad, and Sirsa each had seroprevalence of $80 \%$. Kaithal and Kurukshetra were $60 \%$ and $50 \%$ seropositive, respectively.

\section{Discussion}

BT, an arthropod-borne viral disease, mainly affects sheep and wild ruminants. Among all susceptible vertebrates, sheep are the main hosts [22]. Clinical signs mainly involve fever, nasal discharge, frothy salivation, excoriation of oral mucosa, and laminitis [23]. BTV viral genome is mainly surrounded by two major structural proteins such as VP3 and VP7 and three minor structural proteins such as VP1, VP4, and VP6. This in turn is surrounded by outer capsid containing two structural proteins VP2 and VP5. The VP7 and VP3 polypeptides are predominant and constitute more than 50\% of the total BTV protein structure. The VP7 antigen has been found to be a highly conserved group-specific antigen [24].

Diagnosis of exposure to BTV mainly relies on detecting antibodies to a group-specific antigen. The AGID test is the most widely used assay for this purpose [25]. Although AGID is simple and rapid to perform, it is insensitive and gives cross-reactivity with other orbiviruses like EHDV. The use of monoclonal antibodies against BTV group-specific protein VP7 in c-ELISA can overcome this problem [26]. The serological response in BTV infection appears usually 


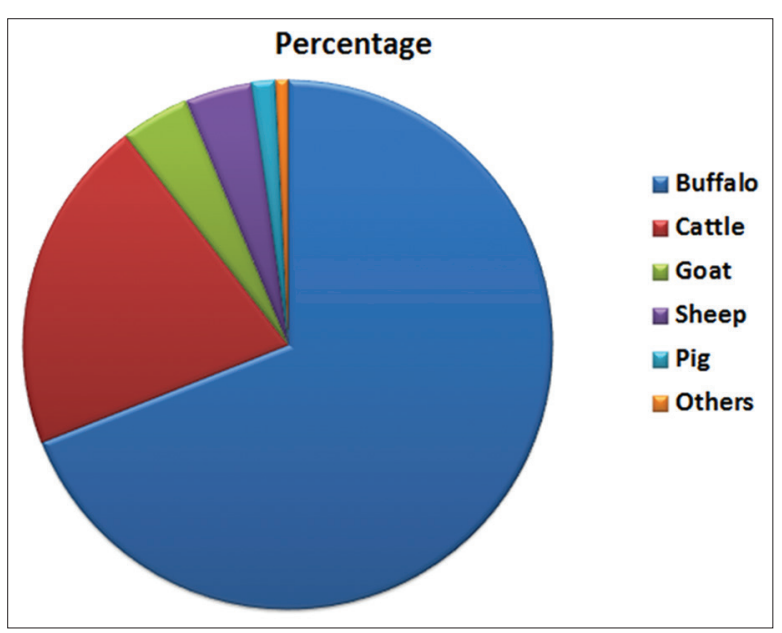

Figure-2: Distribution of livestock in Haryana. Adapted from $19^{\text {th }}$ livestock census 2012, chapter 14, Haryana.

7-14 days post-infection, and antibodies are generally long-lasting.

In India, the occurrence of BT between different parts of the country is dependent on the rainfall, with maximum number of outbreaks occurring during the North-East monsoon, followed by South-West monsoon [27]. In the study presented here, seroprevalence of BTV in cattle and buffalo was found to be $75.29 \%$ and $93.41 \%$, respectively. Buffaloes exhibited higher seroprevalence than cattle. Serological evidence of BTV infection in local and exotic cattle breeds and buffaloes has been reported earlier from several states of India $[28,29]$, indicating inapparent BTV infection in both cattle and buffaloes, although there are no reports of clinical BT in these animals in India.

A BT seroprevalence of $58.33 \%$ was observed in buffaloes in Gujarat [30]. In earlier studies by Raut et al. [31], a high seroprevalene was observed in cattle and buffalo of Maharashtra with $89.80 \%$ and $80 \%$, respectively. However, in the southern state of India in Kerala, Arun et al. [32] reported that the percentage positivity in cattle was $6.9 \%$ which was below the overall prevalence of the disease previously reported in Kerala. Joarder et al. [33] screened a total of 313 animal serum samples (sheep - 68, goat - 195, and cattle - 50). $58.82 \%$ of sheep, $31.79 \%$ of goat, and $70.00 \%$ of cattle serum samples were found positive for the presence of antibodies for BTV. The prevalence of anti-BT antibodies in different agroclimatic zones ranged between 31 and $50 \%$. This study revealed high seroprevalence of BT in cattle, sheep, and goats in Assam, north-eastern state of India. Bhagat et al. [34] tested a total of 510 goat serum samples from different part of Gujarat (western part of India). Among the samples tested, $292(57.25 \%), 202(39.61 \%)$, and $135(26.47 \%)$ samples were found seropositive by c-ELISA, i-ELISA, and AGID test, respectively. Tigga et al. [35] studied serum samples of different small ruminants from Jharkhand (an eastern state of India) for the presence of BTV antibodies. Of the 480 serum samples tested, 83/190 (43.68\%) sheep, 91/210
Table-2: List of districts in different agroclimatic zones of Haryana.

\begin{tabular}{ll}
\hline Eastern zone & Western zone \\
\hline Ambala & Bhiwani \\
Faridabad & Fatehabad \\
Gurugram & Hisar \\
Jhajjar & Mahendergarh \\
Kaithal & Rewari \\
Karnal & Sirsa \\
Kurukshetra & Charkhi Dadri \\
Panipat & \\
Rohtak & \\
Sonipat & \\
Yamunanagar & \\
Panchkula & \\
Palwal & Jind \\
Mewat & \\
\hline
\end{tabular}

Table-3: Agroclimatic zone-wise seroprevalence of BTV in Haryana as assessed by c-ELISA in cattle species.

\begin{tabular}{lccc}
\hline $\begin{array}{l}\text { Agroclimatic } \\
\text { zone }\end{array}$ & $\begin{array}{c}\text { Total } \\
\text { number } \\
\text { of sample } \\
\text { assessed }\end{array}$ & $\begin{array}{c}\text { Total } \\
\text { number of } \\
\text { positive } \\
\text { samples }\end{array}$ & Positivity \% \\
\hline Eastern zone & 303 & 232 & 76.56 \\
Western zone & 105 & 76 & 72.38 \\
\hline
\end{tabular}

c-ELISA =Competitive enzyme-linked immunosorbent assay, BTV=Bluetongue virus

Table-4: Agroclimatic zone-wise BTV seroprevalence in buffaloes of Haryana as assessed by c-ELISA.

\begin{tabular}{lccc}
\hline $\begin{array}{l}\text { Agroclimatic } \\
\text { zone }\end{array}$ & $\begin{array}{c}\text { Total } \\
\text { number } \\
\text { of sample } \\
\text { assessed }\end{array}$ & $\begin{array}{c}\text { Total } \\
\text { number of } \\
\text { positive } \\
\text { samples }\end{array}$ & Positivity \% \\
\hline Eastern zone & 273 & 257 & 94.13 \\
Western zone & 122 & 110 & 90.16 \\
\hline
\end{tabular}

c-ELISA=Competitive enzyme-linked immunosorbent assay, $\mathrm{BTV}=$ Bluetongue virus

Table-5: District-wise seroprevalence of BTV in cattle and buffaloes of Haryana state.

\begin{tabular}{lcc}
\hline Districts & Cattle & Buffalo \\
\hline Ambala & 35.00 & 95.00 \\
Bhiwani & 90.00 & 95.00 \\
Faridabad & 80.00 & 80.00 \\
Fatehabad & 70.00 & 80.00 \\
Gurgaon & 100.00 & 100.00 \\
Hisar & 53.30 & 91.66 \\
Jhajjar & 90.00 & 95.00 \\
Jind & 85.00 & 95.00 \\
Kaithal & 23.30 & 60.00 \\
Karnal & 89.47 & 100.00 \\
Kurukshetra & 66.60 & 50.00 \\
Mahendragarh & 100.00 & 100.00 \\
Mewat & 85.00 & 100.00 \\
Palwal & 100.00 & 100.00 \\
Panchkula & 90.00 & 100.00 \\
Panipat & 65.00 & 100.00 \\
Rewari & 70.00 & 93.33 \\
Rohtak & 100.00 & 100.00 \\
Sirsa & 45.00 & 80.00 \\
Sonepat & 95.00 & 95.00 \\
Yamunanagar & 58.33 & 100.00 \\
\hline
\end{tabular}


$(43.33 \%)$ goats, and 46/80 (57.50\%) cattle were found positive. The results of a study by Tigga et al. [35] showed slightly higher seroprevalence, although not significantly at two degrees of freedom $(5 \%)$, in cattle than sheep and goats in different agroclimatic zones of Jharkhand. Sharma et al. [36] estimated the seroprevalence of antibodies to BTV among domestic ruminants of Grenada. They tested 928 sera samples (cattle - 133, goat - 314, and sheep - 481) using c-ELISA. They found that the overall BTV seroprevalence was $78.4 \%$ (95\% confidence interval $[\mathrm{CI}] \pm 2.65)$. The seropositivity of ovine, caprine, and bovine was found to be $71.7 \%$, (95\% CI, 67.67-75.73\%), 80.2\% (95\% CI, 75.79-84.61\%), and 98.5\% (95\% CI, 96.43$100.57 \%$ ), respectively.

The high seroprevalence of BTV in cattle and buffalo population of Haryana state showed their prior exposure to BTV. The free movement of animals from the adjoining states of Rajasthan and intermixing with other animals for grazing (favoring two-way transmission of virus) along with an increase in the number of adult Culicoides oxystoma (the north Indian vector for BTV) during the rainy season overlaps with the spread of BTV in northern India. Moreover, proper surveillance program based on sero-monitoring can help forecast the possible future outbreaks. Attempts of isolation of the virus from the blood of the seropositive animals of Haryana and serotyping of the virus were not successful. There is no current BTV vaccination program in North India. Future, owing to the presence of large number of non-cross-protecting BTV serotypes circulating in the area, the control of disease in the region is difficult to achieve.

However, recent developments of inactivated or subunit vaccines may in the future help to control the disease in the state.

\section{Conclusion}

Overall seroprevalence of BTV specific antibody in cattle and buffaloes for all 21 districts of Haryana state was found to be $75.49 \%$ and $92.91 \%$, respectively. The prevalence of BTV in different agroclimatic zones ranged between $72-77 \%$ and $90-94 \%$ for cattle and buffalo, respectively. In buffaloes, the BTV seroprevalence was detected to be comparatively higher than in cattle. Conclusively, the study showed the BTV circulation is quite wide spread in cattle and buffalo populations in the Northern part of India.

\section{Authors' Contributions}

SM, AT, and DC: Analyzed the data. SM, AT, DC, and AD: Drafted the manuscript. SM, NK, NSM, VK, and NB: Contacted the officials of State AH department and collection of samples. SM, NK, AT, NSM, and AK: Provided reagents and materials. AT, $\mathrm{KB}, \mathrm{AD}$, and NB: Conducted the experiments. SM, $\mathrm{DC}, \mathrm{AD}, \mathrm{AK}, \mathrm{NK}$, and NSM: Proof read the manuscript and provided the guidance. All authors read and approved the final manuscript.

\section{Acknowledgments}

The farmers, veterinarians, and personnel of the Department of Animal Biotechnology are acknowledged for their help in the study. We acknowledge funding support from DBT Bio-CARe grant (BT/ Bio-CARe/04/261/2011-12), BBSRC-DBT (BT/IN/ Indo-UK/FADH/46/SM/2013) and Rashtriya Krishi Vikas Yojana (RKVY) from the Government of India.

\section{Competing Interests}

The authors declare that they have no competing interests.

\section{References}

1. Verwoerd, D. and Erasmus, B.J. (2004) Bluetongue. In: Coetzer, J.A. and Tustin, R.C., editors. Infectious Diseases of Livestock. $2^{\text {nd }}$ ed. Oxford University Press, Cape Town. p1201-1220.

2. Batten, C.A., Henstock, M.R., Steedman, H.M., Waddington, S., Edwards, L. and Oura, A.L. (2013) Bluetongue virus serotype 26: Infection kinetics, pathogenesis and possible contact transmission in goats. Vet. Microbiol., 162: 62-67.

3. Elbers, A.R.W., Backx, A., Mintiens, K., Gerbier, G., Staubach, C., Hendrickx, G. and van der Spek, A. (2008) Field observations during the bluetongue serotype 8 epidemic in 2006. II. Morbidity and mortality rates, case fatality and clinical recovery in sheep and cattle in the Netherlands. Prevent. Vet. Med., 87: 31-40.

4. Purse, B.V., Mellor, P.S., Rogers, D.J., Samuel, A.R., Mertens, P.P. and Baylis, M. (2005) Climate change and the recent emergence of bluetongue in Europe. Nat. Rev. Microbiol., 3: 171-181.

5. Purse, B.V., Brown, H.E., Harrup, L., Mertens, P.P. and Rogers, D.J. (2008) Invasion of bluetongue and other orb virus infections into Europe: The role of biological and climatic processes. Rev. Sci. Tech., 27: 427-442.

6. Savini, G., Puggioni, G., Melon, G., Marcacci, M., Domenico, M.D., Rocchigiani, A.M., Spedicato, M., Oggiano, A., Manunta, D., Teodor, L., Leone, A., Portanti, O., Cito, F., Conte, A., Orsini, M., Cammà, C., Calistr, P., Giovanninia, A. and Lorusso, A. (2017) Novel putative bluetongue virus in healthy goats from Sardinia, Italy. Infect. Genet. Evol., 51: 108-117.

7. Maan, S., Maan, N.S., Belaganahalli, M.N., Potgieter, A.C., Kumar, V., Batra, K. and Mertens, P.P.C. (2016) Development and evaluation of real time RT-PCR assays for detection and typing of bluetongue virus. PLoS One, 11: e0163014.

8. Bumbarov, V., Golender, N., Erster, O. and Khinich, Y. (2016) Detection and isolation of bluetongue virus from commercial vaccine batches. Vaccine, 34(28): 3317-3323.

9. Wright, I.M.(2014) Serological and Genetic Characterisation of Putative New Serotypes of Bluetongue Virus and Epizootic Haemorrhagic Disease Virus Isolated from an Alpaca. Thesis. North-West University, Potchefstroom, South Africa. p102.

10. Sun, E.C., Huang, L.P., Xu, Q.Y., Wang, H.X., Xue, X.M., $\mathrm{Lu}, \mathrm{P}$. and $\mathrm{Wu}$, D.L. (2016) Emergence of a novel bluetongue virus serotype, China, 2014. Transbound. Emerg. Dis., 63: 585-589.

11. Eschbaumer, M., Hoffmann, B., Konig, P., Teifke, J.P., Gethmann, J.M., Conraths, F.J., Probst, C., Mettenleiter, T.C. and Beer, M. (2009) Efficacy of three inactivated vaccines against bluetongue virus serotype 8 in sheep. Vaccine, 27(31): 4169-4175.

12. Rao, P.P., Hegde, N.R., Reddy, Y.N., Krishnajyothi, Y., Reddy, Y.V., Susmitha, B., Gollapalli, S.R., Putty, K. and Reddy, G.H. (2014) Epidemiology of bluetongue in India. 
Transbound. Emerg. Dis., 62(5): e52-e59.

13. Tabachnick, W.J. (1996) Culicoides variipennis and bluetongue-virus epidemiology in the United States. Annu. Rev. Entomol., 41: 23-43.

14. Sperlova, A. and Zendulkova, D. (2011) Bluetongue: A review. Vet. Med., 56: 430-452.

15. Singh, B. and Prasad, S. (2009) A model based assessment of economic losses due to some important diseases in sheep in India. Indian J. Anim. Sci., 79(12): 1265-1268.

16. OIE. (2008) Blue Tongue, Manual of Diagnostic Tests and Vaccines for Terrestrial Animals (Mammals, Birds and Bees). Vol. 1. OIE, Paris. p195-210.

17. Khalid, H.S., Laith, M.S., Abdul-RasoulMazin, M.N. and Mahir, H.H. (2012) A Serological Surveillance of Bluetongue Disease in Sheep and Goats in Iraq by Using Competitive ELISA Technique, Proceeding of the Eleventh Veterinary Scientific Conference. p89-94.

18. Afshar, A., Eaton, B.T., Wright, P.F., Pearson, J.E., Anderson, J., Jeggo, M. and Trotter, H.C. (1992) Competitive ELISA for sero-diagnosis of bluetongue: Evaluation of group-specific monoclonal antibodies and expressed VP7 antigen. J. Vet. Diagn. Invest., 4: 231-237.

19. Afshar, A., Trotter, H.C., Dulac, G.C. and Reddington, J.J. (1993) Evaluation of a commercial competitive ELISA test kit for the detection of group-specific antibodies to bluetongue virus. J. Vet. Diagn. Invest., 5: 336-340.

20. De, A., Batabyal, S., Biswas, S.K., Chand, K., Singh, R.K. and Mondal, B. (2009) Surveillance of bluetongue virus antibody in goats using a recombinant VP7-based indirect ELISA in the coastal saline area of West Bengal, India. Vet. Ital., 45(2): 339-346.

21. Vandenbussche, F.,Vanbinst, T., Verheyden, B., van Dessel, W., Demeestere, L., Houdart, P., Bertels, G., Praet, N., Berkvens, D., Mintiens, K., Goris, N. and De Clercq, K. (2008) Evaluation of antibody-ELISA and realtime RTPCR for the diagnosis and profiling of bluetongue virus serotype 8 during the epidemic in Belgium in 2006. Vet. Microbiol., 129: 15-27.

22. Shringi, S. and Shringi, B.N. (2008) Comparative efficacy of standard AGID, CCIE and competitive ELISA for detecting bluetongue virus antibodies in indigenous breeds of sheep and goats in Rajasthan, India. J. Vet. Sci., 6(1): 77-79.

23. Radostits, O.M., Gay, C.C., Hinchclif, K.W. and Constable, P.D. (2007) Veterinary Medicine: A Textbook of the Diseases of Cattle, Horses, Sheep, Pigs and Goats. $10^{\text {th }}$ ed. WB Saunders Company, London. p1303.

24. Mecham, J.O. and Wilson, W.C. (2004) Antigen capture competitive enzyme-linked immunosorbent assays using baculovirus-expressed antigens for diagnosis of bluetongue virus and epizootic hemorrhagic disease virus. J. Clin.
Microbiol., 42: 518-523.

25. Pearson, J.E, Carbrey, E.A. and Gustafson, G.A. (1985) Bluetongue and related orb virus diagnosis in the united states. In: Jochim, M.M.B. and Osburn, BI., editors. Bluetongue and Related Orb viruses. Alan R Liss, Inc., New York. p469-475.

26. Anderson, J. (1984) Use of monoclonal antibody in a blocking ELISA to detect group specific antibodies to bluetongue virus. J. Immuno. Met., 74: 139-149.

27. Sreenivasulu, D., SubbaRao, M.V., Reddy, Y.N. and Gard, G.P. (2004) Overview of bluetongue disease, viruses, vectors, surveillance and unique features: The Indian sub-continent and adjacent regions. Vet. Ital., 40(3): 73-77.

28. Chandel, B.S., Kher, H.N., Chauhan, H.C. and Vasava, K.A. (2004) Serological survey of antibodies to bluetongue virus in domestic ruminants in Gujarat. Indian Vet. J., 81(7): 737-740.

29. Prasad, G., Sreenivasulu, D., Singh, K.P., Mertens, P.P.C. and Maan, S. (2009) Bluetongue in the Indian subcontinent. In: Mellor, P., Baylis, M. and Merten, P.C., editors. Bluetongue. Elsevier Ltd., London. p167-195.

30. Chauhan, H.C., Chandel, B.S., Gerdes, T., Vasava, K.A., Patel, A.R., Jadhav, K.M. and Kher, H.N. (2005) Detection of group and serotype specific antibodies to bluetongue virus in buffaloes in Gujarat, India. Buffalo Bull., 24(2): 29-36.

31. Raut, S.D., Deshmukh, V.V. and Aziz, A. (2013) Prevalence of antibodies to bluetongue virus in large ruminants of Marathwada region of Maharashtra state. Vet. World, 6: 416-418.

32. Arun, S., John, K., Ravishankar, C., Mini, M. and Ravindran, R. (2014) Seroprevalence of bluetongue among domestic ruminants in Northern Kerala, India. Trop. Biomed., 31: 26-30.

33. Joardar, S.N., Barkataki, B., Halder, A., Lodh, C. and Sarma, D. (2013) Seroprevalence of bluetongue in north eastern Indian state - Assam. Vet. World, 6: 196-199.

34. Bhagat, A.G., Chandel, B.S., Dadawala, A.I., Chauhan, H.C. and Pathan, V.A. (2014) Seroprevalence of bluetongue virus antibodies in goats of Gujarat. Indian. J. Small Rumi., 20(2): 134-137.

35. Tigga, P., Joardar, S.N., Halder, A., Lodh, C., Samanta, I., Isore, D., Batabyal, K. and Dey, S. (2015) Seroprevalence of bluetongue in ruminants of Jharkhand. Vet. World, 8: 346-349.

36. Sharma, R.N., Beckford, S., Tiwari, K., Vinet, E., Thomas, D., Allie, C. and Alfred, C. (2016) Seroprevalence of bluetongue virus antibody in ruminants from Grenada. Open. J. Vet. Med., 6: 99-103. 